\title{
PERAN GURU PENDIDIKAN PANCASILA DAN KEWARGANEGARAAN (PPKn) DALAM MENAGGULANGI PELANGGARAN TATA TERTIB SISWA DI SMP NEGERI 3 SAMPOLAWA
}

\author{
Dirnawati Sarpan ${ }^{1}$, Karsadi $^{2}$, Muh.Yusuf $^{3}$ \\ Jurusan Pendidikan Pancasila dan Kewarganegaraan \\ Fakultas Keguruan dan Ilmu Pendidikan \\ Universitas Halu Oleo \\ Email: dirnawatisarpan@gmail.com ${ }^{1}$, karsadi@gmail.com $^{2}$, \\ muhyusuf@gmail.com ${ }^{3}$
}

\begin{abstract}
Abstrak: Tujuan dalam penelitian ini adalah 1) Untuk mengetahui peran guru PPKn dalam menanggulangi pelanggaran tata tertib siswa. 2) Upaya apa saja yang dilakukan guru PPKn dalam menanggulangi pelanggaran tata tertib siswa di sekolah SMP Negeri 3 Sampolawa. Metode dalam penelitian ini merupakan metode penelitian deskriptif kualitatif. Tehnik pengumpulan data dalam penelitian ini adalah observasi,wawancara dan dokumentasi. Adapun analisis data yang digunkan dalam penelitian ini adalah merangkum data, menyajikan data dan menarik kesimpulan. Hasil penelitian menunjukkan bahwa 1. Peran Guru Pendidikan Pancasila dan Kewarganegaraan (PPKn) dalam Menanggualangi Pelanggaran Tata tertib Siswa di SMP Negeri 3 Sampolawa dilakukan melalui 1) Peran guru sebagai pembimbing yaitu, melalui pembimbingan sikap yang di arahkan pada kegiatan ekstrakurikuler pramuka, mengadakan pengayaan, solat berjamaah, datang tepat waktu. 2) Peran sebagai model, dilakukan dengan memberikan contoh ajakan yang baik kepada siswa, baik dalam hadir lebih awal, berpakaian rapi, bertingkah laku yang sopan, dan bertutur kata baik 3) Peran sebagai agen moral yaitu melalui mata pelajaran PPKn dengan mengintegrasikan nilai-nilai kesederhanaan dengan nilai demokratis 4) Peran sebagai komunikator yaitu dengan cara menjadi orang tua dan sahabat bagi siswa sehingga memudahkan dalam berkomunikasi dengan siswa dalam mencari tau masalah atau penyebab siswa melakukan pelanggaran. 2. Upaya guru PPKn dalam menaggulangi pelanggaran tata tertib siswa di SMP Negeri Sampolawa yaitu melalui 1) upaya preventif dengan cara menanamkan kedisiplinan, memberikan motivasi, dan memberikan nasehat. 2) upaya kuratif dengan cara memberikan peringatan, ancaman dan hukuman.
\end{abstract}

\section{Kata Kunci: Peran Guru, Pelanggaran Siswa}

\section{PENDAHULUAN}

Remaja merupakan usia atau tahap seorang siswa mencari jati diri. Pergaulan siswa yang tanpa arah dan kurangnya pengawasan terhadap tingkah laku mereka akan mempunyai kecenderungan mengarah pada pergaulan remaja yang negatif. Dalam usia remaja perlu adanya kebebasan untuk mengembangkan setiap potensi yang ada di dalam diri remaja tersebut, namun kebebasan seorang siswa harus diikuti dengan adanya arahan dan pengawasan terhadap tingkah laku mereka. Tanpa disadari bahwa kebebasan yang kurang bertanggung jawab akan merugikan diri sendiri, keluarga dan masyarakat. 
Pendidikan anak diawali saat mereka berada pada lingkungan keluarga terutama oleh orang tua melalui proses sosialisasi norma dan aturan moral dalam keluarga sosial anak, setelah itu baru diperkenalkan kepada pendidikan formal melalui sekolah. Sekolah sebagai tempat sosialisasi kedua setelah keluarga berperan besar dalam menumbuhkan kesadaran pada diri anak. Penanaman kebiasaan bersikap dan berbuat baik pada anak sangat dipengaruhi oleh lingkungan sekolah tempat ia belajar.

Sekolah merupakan sebuah sarana dan prasarana guna mewujudkan pembangunan nasional di bidang pendidikan. Undang-undang No. 20 Tahun 2003 tentang Sistem Pendidikan Nasional pasal 3 bahwa pendidikan nasional berfungsi untuk mengembangkan kemampuan dan membentuk watak serta peradaban bangsa yang bermartabat dalam rangka mencerdaskan kehidupan bangsa. Oleh karena itu, agar tujuan tersebut dapat tercapai secara optimal, maka diperlukan kesadaran bagi setiap warga negaranya agar mematuhi setiap hukum yang berlaku baik hukum tertulis maupun tidak tertulis. Hal ini sangat diperlukan, karena dari kepatuhan terhadap aturan inilah yang akan menimbulkan disiplin dalam diri setiap warga negara. Penanaman disiplin kepada seseorang perlu dibina sejak dini di mana sekolah merupakan tempat yang tepat guna penanaman disiplin tersebut.

Penanaman disiplin merupakan bagian yang sangat penting dari tugas sekolah. Penanaman nilai moral dan kegiatan belajar mengajar dapat berjalan dengan baik jika setiap sekolah menerapkan tata tertib atau peraturan yang mengatur tata krama dan pergaulan dalam lingkungan sekolah. Oleh karena itu, setiap warga sekolah wajib melaksanakan ketentuan tata tertib sekolah secara konsekuensi dan penuh kesadaran. Di sekolah semua guru bertugas memberikan bimbingan kedisiplinan kepada siswa. Hal itu dilakukan, karena banyak siswa kurang menyadari betapa pentingnya kedisiplinan dalam kehidupan mereka.

Peran guru sebagai pendidik merupakan peran yang berkaitan dengan tugas memberi bantuan dan dorongan (support), tugas pengawasan dan pembinaan (supervisor) serta tugas yang berkaitan dengan mendisiplinkan siswa agar patuh terhadap tata tertib sekolah dan norma hidup dalam keluarga dan masyarakat. Tugas-tugas ini berkaitan dengan meningkatkan pertumbuhan perkembangan anak untuk memperoleh pengalaman-pengalaman lebih lanjut seperti penggunaan kesehatan jasmani, bebas dari orang tua, dan orang dewasa yang lain, moralitas tanggung jawab kemasyarakatan, pengetahuan dan keterampilan dasar, persiapan untuk perkawinan dan hidup berkeluarga, pemilihan jabatan, dan hal-hal yang bersifat personal dan spiritual. Oleh karena itu, tugas guru dapat disebut pendidik dan pembimbing anak. Guru sebagai penanggung jawab dalam mengontrol setiap aktivitas peserta didik agar tingkah lakunya tidak menyimpang dengan normanorma yang ada.

Berdasarkan hasil observasi yang dilakukan di SMP Negeri 3 Sampolawa, pelanggaran-pelanggaran tata tertib yang dilakukan oleh siswa yaitu terlambat datang di sekolah, membolos, tidak memakai atribut dan masih banyak lagi tindakan yang melanggar tata tertib sekolah. Tata tertib seharusnya ditaati oleh setiap siswa dengan penuh kesadaran. Jika terjadi suatu pelanggaran sekarang ini, pihak sekolah berusaha untuk mencari cara mencegah dan menanggulangi pelanggaran-pelanggaran tata tertib yang telah dilakukan oleh siswanya. Agar peraturan tata tertib tersebut, bisa ditaati oleh siswa dan kegiatan sekolah bisa berjalan dengan lancar. Dengan demikian, diperlukan seorang guru Pendidikan 
Pancasila dan Kewarganegaraan (PPKn) yang pada umumnya memiliki keilmuan berkaitan dengan budi pekerti, karena budi pekerti sangat penting untuk diberikan kepada siswa, karena budi pekerti adalah induk dari segala etika, tata krama, tata susila, dan perilaku dalam pergaulan.

Berdasarkan uraian di atas, maka penilis merumuskan masalah penelitian ini yaitu : 1).Bagaimana peran guru PPKn dalam menanggulangi pelanggaran tata tertib siswa di SMP N3 Sampolawa. 2) Upaya apa saja yang dilakukan guru PPKn dalam menanggulangi pelanggaran tata tertib siswa di sekolah SMP Negeri 3 Sampolawa.

Peranan adalah sebuah kegiatan yang dilakukan karena adanya sebuah keharusan maupun tuntutan dalam sebuah profesi atau berkaitan dengan keadaan dan kenyataan.jadi peran merupakan perilaku yang diharapkan oleh orang lain terhadap seseorang yang sesuai dengan kedudukannya dalam suatu sistem. Jadi, peran dipengaruhi oleh keadaan sosial baik dari dalam maupun dari luar. Perilaku individu dalam kesehariannya hidup bermasyarakat berhubungan erat dengan peran.Karena peran mengandung hal dan kewajiban yang harus dijalani oleh seseorang individu dalam bermasyarakat. Semuah harus dijalankan sesuai dengan norma-norma yang berlaku juga di masyarakat. Seorang individu akan terlihat status sosialnya hanya dari peran yang dijalankan dalam kesehariannya(Fauzi, 2013: 3).

Secara umum pengertian guru adalah orang yang memberikan ilmu pengetahuan kepada peserta didik. Guru adalah semua orang yang berwenang dan bertanggung jawab terhadap pendididkan murid-muridnya, baik secara individual ataupun kelompok, baik di sekolah maupun diluar sekolah. Guru dalam pandangan masyarakat adalah orang yang melaksanakan pendidikan tempat-tempat tertentu tidak mesti pendidikan formal, tetapi bisa juga dimesjid, di mushola, di rumah dan sebagainya. Guru memang menempati kedudukan yang terhormat di masyarakat. Kewibawaanlah yang menyebabkan guru di hormati, sehingga masyarakat tidak meragukan figur guru. Masyarakat yakin bahwa gurulah yang dapat mendidik anak didik mereka menjadi orang yang berkepribadian mulia. Kepercayaan yang diberikan masyarakat, maka dipundak guru diberikan tugas dan tanggung jawab yang berat, tapi lebih berat lagi mengembang tanggung jawab. Sebab tanggung jawab guru tidak hanya sebatas di sekolah, tetapi juga di luar sekolah. Pembinaan yang diberikanpun tidak hanya secara kelompok, tetapi juga secara individual. Hal ini tidak mau menuntut guru agar selalu memperhatikan sikap, tingkahlaku dan perbuatan anak didiknya, tidak hanya di lingkungan sekolah tetapi di luar sekolah sekalipun. (Djamarah, 2014: 31)

Peran guru sebagai pendidik merupakan peran yang berkaitan dengan tugas memberi bantuan dan dorongan (support), tugas pengawasan dan pembinaan (supervisor) serta tugas yang berkaitan dengan mendisplinkan siswa agar patuh terhadap aturan-aturan sekolah dan norma hidup dalam keluarga dan masyarakat. Tugas-tugas ini berkaitan dengan meningkatkan pertumbuhan dan perkembangan anak untuk memperoleh pengalaman-pengalaman lebih lanjut seperti penggunaan kesehatan jasmani, bebas dari orang tua dan orang dewasa yang lain, moralitas tanggung jawab kemasyarakatan, pengetahuan dan keterampilan dasar, persiapan untuk perkawainan dan hidup berkeluarga, pemilihanjabatan,, dan hal-hal yang bersifat personal dan spiritual. Oleh karena itu guru tugas guru dapat disebut pendidik dan pembimbing anak. Guru sebagai penanggung jawab dalam 
mengontrol setiap aktivitas siswa agar tingkahlakunya tidak menyimpang dengan norma-norma yang ada (Suyatno, 2011: 12).

Mulyasa (2011: 35) bahwa peran guru sangat membantu dalam perkembangan siswa untuk mewujudkan tujuan hidupnya secara optimal. Keyakinan ini muncul karena manusia adalah manusiah lemah yang dalam perkembangannya senantiasa membutuhkan orang lain, sejak lahir bahkan pada saat meninggal. Semua itu menunjukkan bahwa setiap orang membutuhkan orang lain dalam perkembangannya, demikian halnya dengan peserta didik, ketika orang tua mendaftarkan anaknya ke sekolah pada saat itu juga ia menaruh harapan terhadap guru agar anaknya dapat berkembang secara optimal.

Guru merupakan suatu komponen yang penting dalam penyelenggaraan pendidikan, yang bertugas menyelenggarakan kegiatan mengajar, melatih, meneliti, mengembangkan, mengelolah, dan memberikan pelayanan teknis dalam bidang pendidikan. Seorang guru tugasnya mengajar, maka dia harus mempunyai wewenang mengajar berdasarkan kualifikasi sebagai tenaga pengajar. Sebagai tenaga pengajar guru harus mempunyai kemampuan professional dalam proses belajar mengajar. Dari kemampuan itu, guru dapat melaksanakan peranannya yaitu:

1. Sebagai fasilitator. yang menyediakan kemudahan-kemudahan dalam memberikan sarana-sarana bagi siswa untuk melakukan kegiatan belajar. Lingkungan belajar yang tidak menyenangkan, suasana ruang kelas yang pengap, meja kursi yang berantakan, fasilitas belajar yang kurang tersedia, menyebabkan siswa menjadi malas.

2. Sebagai pembimbing. guru berkewajiban memmberikan bantuan kepada siswa agar mereka mampu menemukan masalahnya sendiri, memecahkan masalahnya sendiri, mengenal diri sendiri, dan menyesuaian lingkungannya. Siswa membutuhkan bantuan guru dalam hal mengatsi kesulitan-kesulitan pribadi, kesulitan pendidikan, kesulitan dalam hubugan sosial, dan interpersonal.

3. Sebagai model. yang mampu memberikan contoh yang baik kepada siswanya agar berperilaku yang baik.

4. Sebagai agen moral. yang turut membina moral masyarakat, peserta didik, serta menunjang upaya-upaya pembangunan.

5. Sebagai komunikator. yang melakukan komunikasi dengan siswa dan masyarakat.

6. Sebagai supervisor. guru hendaknya dapat membatu, memperbaiki, dan menilai secara kritis terhadap proses pengajaran.

7. Sebagai innovator. yang turut menyebar luaskan usaha-usaha pembaharuan kepada masyarakat.

8. Sebagai inisiator. dalam peranan sebagai inisiator, guru harus dapat menjadi pencetus ide-ide dalam pendidikan dan pengajaran.

9. Sebagai manajer. yang memimpin kelompok siswa dalam kelas sehingga proses pembelajaran berhasil (Hamalik, 2015: 9).

Pelanggaran adalah perilaku yang menyimpang untuk melakukan tindakan menurut kehendak sendiri tanpa memperhatikan peraturan yang telah dibuat. Sedangkan pelanggaran menurut tarmidzi dalam website adalah "tidak terlaksana peraturan atau tata tertib secara konsisten menjadi salah satu penyebab utama 
terjadi berbagai bentuk pelanggaran yang dilakukan siswa baik di dalam maupun di luar sekolah.

Menurut (Nawawi 1986: 39) pelanggaran yang dilakukan oleh siswa terhadap tata tertib sekolah disebabkan oleh beberapa faktor yaitu:

a. Faktor Intern

Faktor intern adalah faktor yang bersumber dari dalam diri individu yang meliputi:

1) Keadaan badan yaitu adanya suatu gangguan berupa penyakit yang diturunkan dari orang tua misalnya, peradangan otak, keracunan, kelenjar endoktrin, gangguan pembuluh dara otak, tumor otak dan sebagainya.

2) Kondisi psikologi yaitu adanya perasaan rendah diri, perasaan tertekan yang terus menerus, konflik-konflik yang bertentangan, dan sebagainya.

b. Faktor Ekstern

Faktor ekstern adalah faktor yang bersumber dari luar diri individu yang meliputi:

1) Keadaan lingkungan masyarakat yaitu perubahan-perubahan yang terjadi di masyarakat seperti pertentangn sosial, kekacauan ekonomi, terjadinya diskriminasi tentang sesuatu, persaingan yang tidak adil dan sebagainya.

2) Keadaan lingkungan sekolah yaitu lingkungan sekolah yang selalu berada dalam tekanan dan ketegangan, perlakuan guru yang tidak adil, disiplin yang terlalu keras, hukuman yang tidak menunjang tercapainya tujuan pendidikan, kurang adanya interaksi antara guru dan murid sering dapat memberikan pengaruh pada peserta didik.

3) Keadaan lingkungan keluarga berupa kondidi-kondisi keluarga seperti kurangnya perhatian orang tua terhadap anak, kurangnya hubungan cinta kasih, sikap yang terlalu otoriter, dan adanya suasana kehidupan keluarga yang kurang harmonis.

Menurut (Arikunto 1997: 123) berpendapat batasan antara peraturan dan tata tertib sekolah sebagai berikut:

a. Peraturan menunjuk pada patokan atau standar yang sifatnya umum yang harus dipenuhi oleh siswa. Misalnya peraturan tentang kondisi yang harus dipenuhi oleh siswa di dalam kelas pada waktu pelajaran sedang berlangsung.

b. Tata tertib sekolah menunjuk pada patokan atau standar yang sifatnya khusus yang harus dipenuhi oleh siswa. Tata tertib sekolah menunjuk pada patokan atau standar untuk aktifitas khusus, seperti penggunaan pakaian seragam, penggunaan laboratorium, mengikuti upacara bendera, mengerjakan tugas rumah, pembayaran SPP dan sebagainya.

Adapun upaya menanggulangi pelanggaran tata tertib siswa dapat dilakukan dengan upaya prevensif. Yang dimaksud dengan upaya prevensif adalah kegiatan yang dilakukan secara sistematis, berencana, dan terarah, untuk menjaga agar kenakalan itu tidak timbul. Upaya prevensif lebih besar manfaatnya dari pada upaya kuratif, karena jika kenakalan itu sudah meluas, amat sulit menanggulanginya.

Menurut Soedjono Dirjosiswo, (Sudarsono, 2012: 130-131). Mengemukakan upaya menanggulangi pelanggaran tata tertib siswa dapat dilakukan dengan dua cara yaitu (1) Upaya preventif dan (2) Upaya Kuratif. 
a. Upaya preventif

Upaya preventif adalah upaya yang dilakukan secara sistematis, berencana, dan terarah, untuk mencegah agar pelanggaran itu tidak dilakukan. Upaya prepentif merupakan segala tindakan yang bertujuan untuk mencegah timbulnya pelanggaran-pelanggaran. Upaya prepentif biasanya dilakukan dengan cara:

1. Menanamkan kedisiplinan.

disiplin merupakan suatu sikap mental yang dengan kesadaran dan keinsafaanya mematuhi terhadap perintah-perintah atau larangan yang ada terhadap suatu hal. Karena memahami betul tentang pentingnya larangan tersebut. Karena itu disiplin hrus ditanamkan dalam sanubari siswa.

2. Memberikan motivasi

Guru hendaknya dapat mendorong siswa agar bergairah dan aktif belajar. Selain memotivasi siswa agar semangat dalam belajar disamping itu juga guru harus bisa memotivasi siswa pada pembentukan akhlak yang baik, yang mana akhlaq merupakan keseluruhan dari gerak hidup manusia

3. Memberikan nasehat

dalam bahasa Indonesia kata nasehat diartikan sebagi ajaran atau pelajaran yang baik. Guru adalah penasehata bagi siswa, bahkan bagi orang tua, meskipun mereka tidak memiliki latihan khusus sebagai penasehat dan dalam beberapa hal tidak dapat berharap untuk menasehati orang. Menjadi guru pada tingkat manapun berarti menjadi penasehat dan menjadi orang kepercayaan, dan mampu menasehati siswa kedalam hal-hal positif bahkan kegiatan pembelajaranpun meletakkannya pada posisi tersebut

b. Upaya Kuratif

Yang dimaksud dengan upaya kuratif dalam manggulangi pelanggaran siswa dengan upaya antisipasi terhadap gejala-gejala pelanggaran tersebut, supaya pelanggaran itu tidak meluas dan merugikan sekolah dan masyarakat.

Penaggulangan pelanggaran tata tertib siswa dengan upaya kuratif yaitu (1) memberikan peringatan, dan (2) memberikan hukuman

1. Peringatan diberikan terhadap siswa yang sudah berkali-kali melakukan pelanggaran dimana sebelumnya sudah diberi teguran dan biasanya pelanggara itu disertai dengan ancaman apabila hal tersebut terulang kembali.

2. hukuman adalah tindakan yang paling akhir terhadap pelanggaran yang sudah berkali-kali dilakukan setelah diberitahukan, dan diperingati. ketika pelanggaran telah dilakukan berulang-ulang maka cara menanggulainginya yaitu dengan memberikan hukuman pada siswa yang melakukan pelanggaran.

\section{METODE PENELITIAN}

Penelitian ini dilaksanakan di SMP Negeri 3 Sampolawa, Kecamatan Sampolawa Kabupaten Buton Selatan pada bulan April 2017 sampaiselesai. penelitian ini bersifat deskriptif dengan pendekatan kualitatif dengan tujuan untuk menggambarkan dan menjelaskan tentang peran guru PPKn dalam menanggulangi pelanggaran tata tertib siswa diSMP Negeri 3 Sampolawa. Untuk memperoleh data yang dibutuhkandalam penelitian ini digunakan teknik pengumpulan data yaitu observasi, wawancara, dan dokumentasi. Teknik analisis data yang digunakan dalam penelitian ini adalah redusi data, kesimpulan dan penerikan kesimpulan. 


\section{HASIL DAN PEMBAHASAN}

Sekolah Menengah Pertama (SMP) Negeri 3 Sampolawa didirikan dan mulai beroperasi pada tahun 2005 dengan status Sekolah Swasta dan diresmikan pada tahun 2006 dengan status Sekolah Negeri. Letaknya berada di Jalan Teo Indah No. 01Gunung Sejuk, Desa Gunung Sejuk KecamatanSampolawa Kabupaten Buton Selatan. Status Bangunan adalah milik Pemerintahserta luas seluruh bangunan $100 \mathrm{~m} \times 100 \mathrm{~m}$. Jenis bangunannya adalah permanen yang berkedudukan di atas tanah seluas $19.980 \mathrm{~m}^{2}$. Kemudian batas-batas yang mengelilingi lingkungan Sekolah Menengah Pertama ini yaitu: sebelah utara berbatasan dengan warga dusun laporoworu, sebelah barat berbatasan langsung dengan perkebunan milik warga setempat sebelah selatan berbatasan dengan pemukimanwarga desa lipimangau, sebelah timur berbatasan dengan perkebunan milik warga setempat, dengan status tanah sepenuhnya milik Negara. SMP Negeri 3 Sampolawa merupakan salah satu sekolah menengah pertama yang ada di Kecamatan Samoplawa dan memiliki sarana dan prasarana fisik yang cukup memadai yang dapat menunjang kelancaran pelaksanaan proses belajar mengajar di sekolah.

\section{Peran Guru Pendidikn Pancasila Dan Kewargarganegraan Dalam Menanggulangi Pelanggaran Tata Tertib Siswa}

a) Peran Sebagai Pembimbing

Dalam menanggulangi pelanggaran tata tertib siswa di SMP Negeri 3 Sampolawa dilakukan dengan bimbingan langsung terhadap siswa yang melakukan pelangggaran melalui pendekatan secara individu untuk bisa membantu siswa mengenal diri sendiri, serta berusaha membantu mengatasi kesulitan, masalah dan penyebab siswa melakukan pelanggaran, dengan cara menjalin hubungan yang akrab, penuh kehangatan dan saling percaya, termasuk di dalamnya berusaha menjaga kerahasiaan data siswa yang kami bimbing apabila data itu bersifat pribadi. Kami juga membimbing siswa yang melakukan pelanggaran melalui pembimbingan sikap, tingkahlakunya kami arahkan pada kegiatan yang melatih kedisiplinan mereka seperti kegiatan ekstrakurikuler pramuka, mengadakan pengayaan, solat berjamaah, datang tepat waktu.

b) Peran Guru Sebagai Model

Dalam menanggulangi pelanggaran tata tertib siswa di SMP Negeri 3 Sampolawa dilakukan dengan lebih dahulu melakukan apa yang seharusnya kami contohkan misalnya : ajakan yang baik kepada siswa, baik dalam hadir lebih awal, berpakaian rapi, bertingkah laku yang sopan, dan bertutur kata baik, sehingga menarik perhatian siswa untuk melakukan hal yang sudah kami contohkan seperti, selalu datang tepat waktu, berpakaian rapi, berperilaku sopan, dan bertutur kata yang baik sesuai aturan yang berlaku di sekolah dengan harapan siswa tidak melakukan pelanggaran tata sekolah

c) Peran Guru Sebagai Agen Moral

Dalam menanggulangipelanggaran tata tertib siswa di SMP Negeri 3 Sampolawa dilakukan melalui penilaian sikap dalam kehidupan keseharian siswa, dikasih contoh tingkahlaku yang sesuai moral dan tidak melanggar norma-norma yang ada. Selain itu, peran kami dalam mendidik moral siswa juga melalui mata pelajaran PPKn dengan mengintegrasikan nilai-nilai kesederhanaan dengan nilai 
demokratis misalnya: tidak menggunakan perhiasan yang mencolak, menghargai pendapat orang lain, dan tidak memaksakan kehendak dalam bermusyawarah.

d) Peran Guru Sebagai Komunikator

Dalam menanggulangipelanggaran tata tertib siswa di SMP Negeri 3 Sampolawa dilakukan dengan cara menjadi orang tua dan sahabat bagi siswa sehinggad memudahkan kami berkomunikasi dengan siswa dalam mencari tau masalah atau penyebab siswa melakukan pelanggaran, sehingga kami dapat memberikan solusi, pemahaman dan kesadaran kepada siswa untuk tidak melakukan pelanggaran-pelanggaran norma yang berlaku di sekolah.

\section{Upaya Guru Pendidikan Pancasila Dan Kewarganegaraan Di SMP Negeri 3 Sampolawa Dalam Menanggulangi Pelanggaran Tata Tertib Siswa}

1) Upaya Preventif

a. Menanamkan kedisiplinan

Dalam menanggulangi pelanggaran tata tertib siswa di SMP Negeri 3 Sampolawa dilakukan dengan upaya preventif atau upaya pencegahan dengan cara menanamkan kedisiplinan kepada siswa. Sebab kedisiplinan sangat penting dalam aspek kehidupan manusia. Adapun penanaman kedisiplinan kepada siswa, di lakukan dengan cara pembiasaan, dengan contoh dan teladan, dengan penyadaran, dan dengan pengawasan atau kontrol

b. Memberikan motivasi

Dalam menanggulangi pelanggaran tata tertib siswa di SMP Negeri 3 Sampolawa dilakukan dengan cara memberikan motivasi kepada siswa. Sebab dengan memberikan motivasi yang di arahkan pada perbaikan ahlaq melalui penanaman moral pada siswa, sehingga siswa tau mana perbutan baik dan mana perbuatan yang buruk. dengan begitu dapat membantu mencegah siswa untuk tidak melakukan pelanggaran-pelanggaran yang berlaku di sekolah.

c. Memberikan nasehat

Dalam menanggulangi pelanggaran tata tertib siswa di SMP Negeri 3 Sampolawa dilakukan dengan memberikan nasehat yang baik kepada siswa. kami memberikan nasehat memgenai kelalaian atau perilaku yang mereka lakukan itu tidak baik untuk diri mereka, orang tua dan juga untuk kebaikan sekolah kedepannya. Tujuan diberikannya nasehat yaitu agar siswa tidak melakukan pelanngaran-pelanggaran tata tertib sekolah.

2) Upaya Kuratif

a. Peringatan dan Ancaman

Dalam menanggulangi pelanggaran tata tertib siswa di SMP Negeri 3 Sampolawa dilakukan dengan cara meberikan peringatan kepada siswa yang melakukan pelanggaran dengan menegur terlebih dahulu dan kemudian memberikan ancaman akan dikeluarkan dari sekolah apabila pelanggaranpelanggaran terhadap tata tertib sekolah terus mereka lakukan dilakukan.

b. Memberikan Hukuman

Dalam menanggulangi pelanggaran tata tertib siswa di SMP Negeri 3 Sampolawa dilakukan dengan cara meberikan hukuman kepada siswa yang melakukan pelanggaran. Hukuman yang kami berikan yaitu membersihkan WC, membersihkan lingkungan sekolah, tidak mengizinkan siswa yang melanggar untuk mengikuti proses pembelajaran di kelasbahkan kami mengeluarkan siswa 
tersebut dari sekolah" Tujuan diberikannya hukuman yaitu agar siswa tidak melakukan pelanngaran dan tidak mempengarihi siswa lain.

\section{PENUTUP}

\section{Kesimpulan}

sebagai berikut:

1. Peran guru Pendidikan Pancasila dan Kewarganegaraan dalam menanggulangi pelanggaran tata tertib siswa di SMP Negeri 3 Sampolawa melalui peran guru sebagai fasilitator yaitu menyediakan kemudahan-kemudahan untuk siswa dalam kegiatan belajar mengajar, peran guru sebagai pembimbing, yaitu dengan bimbingan sikap yang diarahkan pada perilaku yang baik. Peran sebagai model yaitu dengan terlebih dahulu memberikan contoh berpakaian dengan rapi, datang tepat waktu, berperilaku sopan, dan berkata-kata dengan baik. Peran guru sebagai agen Moral yaitu dengan melakukan penilaian sikap siswa dalam kesehariannya di sekolah, dan Peran guru sebagai komunikator yaitu memberikan nasehat-nasehat yang baik kepada siswa.

2. Upaya guru Pendidikan Pancasila dan Kewarganegaraan dalam menanggulangi pelanggaran tata tertib siswa di SMP Negeri 3 Sampolawa dilakukan dengan dua cara yaitu 1) upaya preventif yaitu segala upaya yang bertujuan untuk mencegah timbulnya pelanggaran-pelanggaran dengan cara menanamkan kedisiplinan, memberikan motivasi, dan memberikan nasehat. 2) upayakuratif adalah upaya menaggulangi terhadap pelanggaran-pelanggaran yang telah dilakukan oleh siswa, supaya pelanggaran itu tidak meluas dan merugikan sekolah dan masyarakat dengan cara memberikan peringatan, ancaman dan hukuman.

\section{Saran}

1. Kepada guru Pendidikan Pancasila dan Kewarganegaraan di SMP Negeri 3 Sampolawa diharapkan mampu meningkatkan kualitas pelayanan pembinaan dan bimbingan dalam menanggulangi pelanggaran tata tertib siswa, agar pembinaan dan pemberian bimbingan dalam menanggulangi pelanggaran tata tertib siswa dapat tercapai dan berhasil secara optimal.

2. Kepada orang tua siswa diharapkan dapat berpartisipasi dalam mewujudkan panggilan daari pihak sekolah dalam pelaksanaan pembinaan dan bimbingan guna menanggulangi pelanggaran tata tertib siswa agar dapat terlaksana dengan baik.

3. Kepada siswa diharapkan dapat mematuhi peraturan tata tertib sekolah dan mau menerima nasehat yang diberikan oleh guru Pendidikan Pancasila dan Kewarganegaraan, agar tercipta sekolah yang damai, dan aman sehingga menunjang keberhasilan sekolah kedepannya.

\section{DAFTAR PUSTAKA}

Arikunto suharsimi, Manajeman Pengajaran Secara Manusia, Jakarta: Rineka Cipta 1997).

Djamarah, Syaiful Bahri. 2014. Guru dan Anak didik dalam Interaksi Edukatif. Jakarta: Rineka Cipta. 
Fauzi. 2013. Peran Guru Pendidikan Pancasila dan Kewarganegaran Dalam Upaya Pembentukan Karakter Peserta Didik. Jurnal PPKn UNJ Online.http://skripsippknunj.org

Hamalik, Oemar. 2015. Kurikuklum dan Pembelajaran. Jakarta: Bumi Aksara.

Mulyasa, E. 2011. Menjadi Guru Profesional. Bandung: PT Remaja Rosdakarya

Nawawi, Hadari. 1986. Organisasi Sekolah dan Pengelolaan Kelas Sebagai Lembaga Pendidikan. Jakarta: Gunung Agung.

Suyatno. 2011. Peran Guru Pendidikan Kewarganegaraan Dalam Mencegah Kenakalan Peserta Dididk Di SMP Negri 1 Tanggungharjo kabupaten Grobogan. http://Skrpsi. lib.linnes ac. id. Pdf.

Sudarsono. 2012. Kenkalan Remaja. Jakarta: Rinaka Cipta 